Department of Reproduction, Research Institute for Animal Breeding and Nutrition, Herceghalom, Hungary'; Department of Obstetrics and Gynecology, Faculty of Veterinary Science, Szent Istvan University, Budapest, Hungary $^{2}$ and Department of Reproductive Biology, Research Institute for the Biology of Farm Animals, Dummerstorf, Germany ${ }^{3}$

ISTVAN EGERSZEGI ${ }^{1}$, JOZSEF RÁTKY ${ }^{1}$, LÁSZLÓ SOLTI ${ }^{2}$ and KLAUS-PETER BRÜSSOW ${ }^{3}$

\title{
Mangalica - an indigenous swine breed from Hungary (Review)
}

\begin{abstract}
Nowadays there is an increased demand to preserve the biological diversity in wild and farm animals. In this paper the history, utilisation and reproductive performance of the endangered native Hungarian swine breed Mangalica are reviewed. This fat-type race was the most typical since the middle of the nineteenth century. However, Mangalica nearly disappeared in the 1970-ies due to changing dietary habits and breeding of modern industrial pig breeds. The valuable characteristics of Mangalica, like resistance and excellent adaptability to extreme housing conditions, motherliness and delicious meat taste are recognised anew.
\end{abstract}

Key Words: pig, Mangalica, reproduction, utilisation

\section{Zusammenfassung}

Titel der Arbeit: Mangalitza - Eine typische Schweinerasse aus Ungarn (Übersicht)

Gegenwärtig wächst das Bestreben, die biologische Vielfalt sowohl bei Wild- als auch bei landwirtschaftlichen Nutztieren zu bewahren. In dieser Übersicht werden Geschichte, Nutzung und Reproduktionsleistungen der bedrohten Ungarischen Mangalitza Schweinerasse referiert. Diese Fettschweinrasse war seit Mitte des 19. Jahrhunderts die typischste Rasse in Ungarn. Jedoch war sie seit Beginn 1970 aufgrund veränderter Verzehrgewohnheiten und durch die Zucht moderner industrieller Schweinerassen vom Aussterben bedroht. Die wertvollen Eigenschaften dieser Rasse wie Widerstandsfähigkeit und Anpassung gegenüber extremen Haltungsund Fütterungsbedingungen, Mütterlichkeit und der hervorragende Fleischgeschmack werden gegenwärtig neu erkannt.

Schlüsselwörter: Schwein, Mangalitza, Fortpflanzungsleistungen, Nutzung

\section{Introduction}

The Mangalica is a native Hungarian pig race, which was the most typical breed here till the middle of the last century. It is a fat-type, curly-haired swine with relatively low reproductive performance, but strong motherliness and good adaptability to extensive housing conditions. This breed has nearly disappeared in the nineteenseventies, since in some traits like growth rate, feed conversion, reproductive performance and meat/fat ratio it could not compete with the productivity of commercial white breeds and its products did not suit with the changing dietary habits after the 2nd World War. There were several proposal to convert the characteristics of this breed, but fortunately it was not successful and this aboriginal swine breed has been subsisted. National programs were established in 1976 to preserve the gene pool (BALTAY, 1985; BODÓ, 1997). The real escape from extinction comes with the anew economic exploitation of the Mangalica and nowadays with growing interest to breed endangered animals (this breed was chosen in 1999 the breed of the year in 
Germany by the German Safeguard Society of Ancient and Endangered Domestic Animal Breeds; FLEGLER, 1999). This strategy fits to the demands of the UNCED Conference of Rio 1992 to preserve biodiversity of plants and animals.

\section{History of the breed}

It is quite difficult to find the historical roots of ancient swine breeding in Hungary, since there are not so much archaeological findings. However it is sure, that there was a full blown swine breeding in the country, when the Hungarian's forefathers settled in the Carpathian-basin. The Romans had already developed breeding before, they had to feed a large population of the province. Then the Avars (residents before the Hungarians) have kept the Lápi (moorland) race, which blood-lined with Laibacher Moorland pigs and wild boar. This Lápi race might have been the origin of our three Hungarian aboriginal pig breeds, the Bakony, the Szalonta and the Alföldi fat-type pigs (newborn piglets of these races were stripped which shows the relationship with wild boar). The Bakony and Alföldi were fat-type swine with curly hair, relative small body-weight and roundish body shape. The Szalonta belongs to meat-type, it was a high, bulky, robust and red-coated race (HANKÓ, 1940). All of these races disappeared or were altered till the end of the nineteenth century and by that time the Hungarian Mangalica became the dominant swine breed. The Hungarian Mangalica was formed from crossing of Alföldi, Szalonta and Bakony breeds with the Serbian Sumadia pig, which was bred in the Valley of Morava (ENESEI DORNER, 1925). The first Sumadia stock (9 sows and 2 boars) arrived to Kisjenö in Hungary in 1833 as a gift from Serbian Prince Milos to Archduke József. The cross-breeding originate from these animals, and soon the Sumadia blood could have been found in all large breeding stocks of Hungary. More breeding animals were imported from Serbia to improve the Hungarian Mangalica. However some references had mentioned Mangalica before introduction of Sumadia pigs in 1833 (GÁTI, 1795; SCHWARTNER, 1809; PETHE, 1815; MILOTAI, 1832, all cit. HANKÓ, 1940; MATOLCSY, 1975). Nevertheless, at that time fat-type swine were denominated Mangalica and this population had been standardised by Sumadia. The evolved new race was larger, heavier and fattened better than its vanishing predecessors, and it began the golden age of Hungarian swine breeding with Mangalica.

\section{About the breed}

The earliest describes of Mangalica had mentioned two types, namely the White and Black Mangalica (CZILERT, 1859). Later five colour types of this breed were portrayed: Blond or White, Black, Swallow-Belly and Brown (Baris) one, like wild boar, and at least the Red Mangalica (KOVÁCSY-MONOSTORI, 1890; ENESEI DORNER, 1908, 1921, 1925; HANKÓ, 1940; MATOLCSI, 1975). Nowadays there exist only three types of Mangalica - Blond, Swallow-Belly and Red. Some information about the formation of these types. Most likely the Blond type had been formed by crossing of the small ancient Alföldi pigs and the Serbian Sumadia swine,

\section{Figure legends}

Fig. (above): Multiparous Blond Mangalica sow (Oben - Blonde Mangalitza Altsau)

Fig. (center): Swallow Belly Mangalica gilt (Mitte - Schwalbenbäuchige Mangalitza Jungsau)

Fig. (below): Red Mangalica sow (Unten - Rote Mangalitza Sau) 

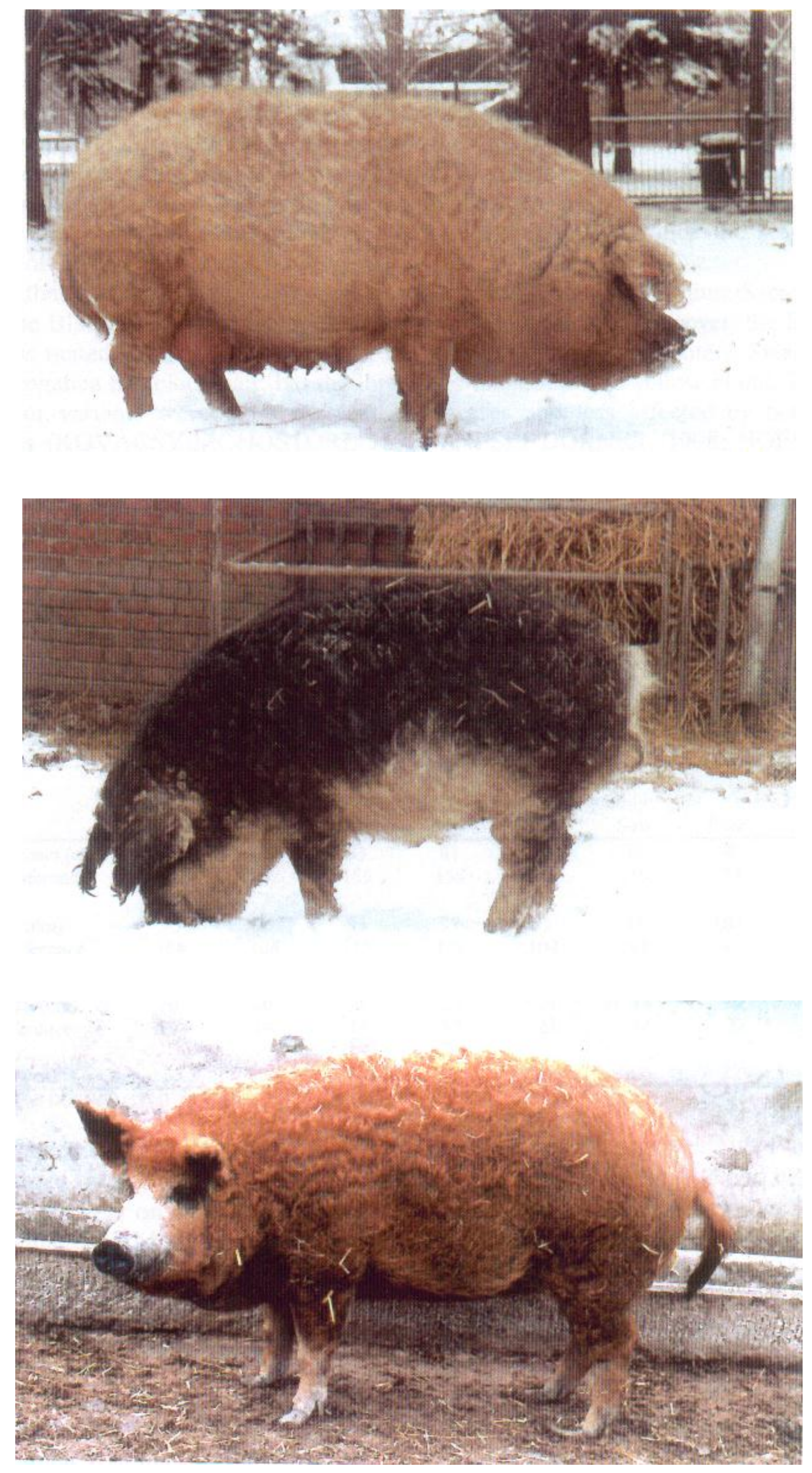
and later they were crossbred with Szalonta and Bakony too. This type was the predominating one. It has short, deep body, fine bone structure and the skin is slate. The toenails/claws, eye-periphery, nose, the natural body-holes and the teats are black in pure-bred animals. The head is rather small, the ears are large and hanging forward. The hair of Blond Mangalica is dense, curly like shavings, glistening like silk and its colour can variegate from grey-yellow to ruddy. The eyelashes, eyebrow and the tip of tail-tassel are always black (Fig., above). Furthermore for Mangalica the seasonal moulting of the hair is typical.

It is told that the Black type was bred by crossing with Croatian Syrmium/Szeremier breed. The Black Mangalica disappeared during the last century. However, the Black swine was mated with Blond one and set the Swallow-Belly (Fig., center). SwallowBelly Mangalica has black hair, but the throat and underbelly are yellow blond. These two colour variants were more resistant to diseases and less affected by housing conditions (KOVÁCSY-MONOSTORI, 1890; ENESEI DORNER, 1908; HOESCH, 1911).

The Red Mangalica (Fig., below) arose by the second part of the nineteenth century. Blond sows were coupled with Szalonta boars and the new type was also called NewSzalonta. This type was more valuably due to meat quality and growing performance, and its characteristics were almost the same like the Blond (HANKÓ, 1940).

Parameters of body measurements of Mangalica boars and sows are presented in Table 1.

Table 1

Parameters of body measurements of adult Mangalica boars and sows (Parameter der Exterieurbeurteilung bei adulten Mangalitza-Ebern und -Sauen)

\begin{tabular}{|c|c|c|c|c|c|c|c|c|}
\hline & \multirow{2}{*}{\multicolumn{2}{|c|}{3 years of age* }} & \multicolumn{6}{|c|}{$2-3$ years of age** } \\
\hline & & & \multicolumn{2}{|c|}{ Blond } & \multicolumn{2}{|c|}{ Swallow Belly } & \multicolumn{2}{|c|}{ Red } \\
\hline & Boar & Sow & Boar & Sow & Boar & Sow & Boar & Sow \\
\hline Height at withers $(\mathrm{cm})$ & 77 & 75 & 83 & 81 & 78 & 78 & 88 & 82 \\
\hline $\begin{array}{l}\text { Chest circumference } \\
(\mathrm{cm})\end{array}$ & 145 & 147 & 155 & 155 & 140 & 150 & 154 & 150 \\
\hline Body length (cm) & 95 & 95 & 96 & 97 & 95 & 98 & 104 & 98 \\
\hline $\begin{array}{l}\text { Neck circumference } \\
(\mathrm{cm})\end{array}$ & 106 & 104 & 115 & 113 & 100 & 108 & 112 & 110 \\
\hline Head length $(\mathrm{cm})$ & 35 & 32 & 28 & 32 & 32 & 26 & 32 & 28 \\
\hline Snozzle length $(\mathrm{cm})$ & 26 & 20 & 18 & 21 & 21 & 18 & 22 & 21 \\
\hline $\begin{array}{l}\text { Shin circumference } \\
(\mathrm{cm})\end{array}$ & 19 & 19 & 19 & 17 & 21 & 18 & 22 & 18 \\
\hline Body weight (kg) & 165 & 150 & 190 & 165 & 165 & 170 & 220 & 180 \\
\hline
\end{tabular}

There had been two housing methods for Mangalica. In estates pigs were kept in large herds grouped by age and sex, and supervised by herdsmen. The animals had been fed throughout the year on pasture and in the oak-beech forest. Sows were introduced only for farrowing. Small-farmers kept their pigs in night time at home in special cages and in the day time all pigs of the village were shepherded on communal pastures.

Generally the farrowing season was in spring and the sows gave birth 4-6 piglets usually. After the suckling period of 8-10 weeks the piglets were kept together and by the age of 4 months boars and gilts were separated. The breeding gilts were kept in droves on pasture and wasteland till the first mating at $15-18$ month of age and reaching a body weight of $80-100 \mathrm{~kg}$ (ENESEI DORNER, 1926; RÁCZ, 1932). The fattening stock was kept in the forest and on the pasture till one year of age followed 
by subsequent 6 months fattening period. Animals were slaughtered at the weight of 150-200 kg. Mangalica has very strong body formation and solid joints, and tolerated well to be driven on foot all the way from the southern frontier through the forest of Bakony to Györ and to Vienna. Later the growing request of the market along with the improved maize production resulted in building of industrial size fattening yards. In the 1880-1890-ies 15-20,000 pigs were fattened all at once in such a yard. The Hungarian lard and salami were wanted products on the market (ENESEI DORNER, 1926). The disastrous swine fever in 1895 and the $1^{\text {st }}$ World War set back the pig breeding, the population decreased from $6,500,000$ to 2,100,000 (RÁCZ, 1932). In the 1920-ies the breeders had requested to establish an organisation, which represent their interest. The conscious breeding of the stock began 1927, when the National Association of Mangalica Breeders (NAMB) was formed. The Association defined the standards of the breed, established the herd book and the registration of breeding animals. Furthermore breeders were provided with instructions and advises for propagation (RÁCZ, 1930, BLANTZ, 1938; KAZÁR, 1955). Table 2 presents the development of Mangalica breeding sows between 1927 and 2001. Evidently, the breeding stock increased until the $2^{\text {nd }}$ World War, then decreased dramatically (the activity of the NAMB was suspended too) and the race nearly disappeared. Only 34 breeding sows were registered in the herd-book in 1975. The race was rescued from extinction by state intervention. It was enacted to breed Mangalica in gene-reserve (BALTAY, 1983; ZENGÖ, 1998).

Table 2

Number of breeding sows in Hungary between 1927-2001 (Anzahl der Zuchtsauen in Ungarn 1927-2001)

\begin{tabular}{|c|c|c|c|c|c|}
\hline YEAR & $\begin{array}{c}\text { RED } \\
\text { MANGALICA }\end{array}$ & $\begin{array}{l}\text { SWALLOW- } \\
\text { BELLY } \\
\text { MANGALICA }\end{array}$ & $\begin{array}{c}\text { BLOND } \\
\text { MANGALICA }\end{array}$ & TOTAL & REFERENCE \\
\hline 1927 & $*$ & $*$ & $*$ & 1000 & \multirow[t]{11}{*}{ BALTAY, 1983} \\
\hline 1930 & $*$ & $*$ & $*$ & 1920 & \\
\hline 1935 & $*$ & $*$ & $*$ & 6500 & \\
\hline 1940 & $*$ & $*$ & $*$ & 20000 & \\
\hline 1943 & $*$ & $*$ & $*$ & 30000 & \\
\hline 1955 & $*$ & $*$ & $*$ & 17691 & \\
\hline 1959 & $*$ & $*$ & $*$ & 4091 & \\
\hline 1965 & $*$ & $*$ & $*$ & 922 & \\
\hline 1970 & $*$ & $*$ & $*$ & 243 & \\
\hline 1975 & $*$ & $*$ & $*$ & 34 & \\
\hline 1980 & $*$ & $*$ & $*$ & 244 & \\
\hline 1988 & 46 & 61 & 222 & 329 & \multirow{14}{*}{$\begin{array}{c}\text { ZENGÖ, 1997; } \\
\text { OMMI, } 2002\end{array}$} \\
\hline 1989 & 64 & 73 & 201 & 338 & \\
\hline 1990 & 62 & 62 & 224 & 348 & \\
\hline 1991 & 66 & 28 & 128 & 222 & \\
\hline 1992 & 43 & 25 & 175 & 243 & \\
\hline 1993 & 31 & 32 & 138 & 201 & \\
\hline 1994 & 28 & 20 & 106 & 154 & \\
\hline 1995 & 20 & 18 & 170 & 208 & \\
\hline 1996 & 38 & 42 & 266 & 346 & \\
\hline 1997 & 32 & 46 & 315 & 393 & \\
\hline 1998 & 39 & 60 & 299 & 398 & \\
\hline 1999 & 50 & 64 & 491 & 605 & \\
\hline 2000 & 75 & 74 & 616 & 765 & \\
\hline 2001 & 179 & 145 & 1001 & 1325 & \\
\hline
\end{tabular}

* No data available; OMMI-National Institute for Agricultural Quality Control 
What was the reason of the fast decline of the Mangalica population? At first there was a change in consumption habits and the breed did not fulfil these requirements. It produced too much lard and its meat was very fatty. Secondly its reproductive and growing performance could not compete with the modern breeds.

After a long interruption, in 1994 the National Association of Mangalica Breeders resumpted its activity and re-organised the registration of animals, the inspection and introduced a certification of origin for every Mangalica products on the market. There is an obligatory blood control of breeding sows and boars. The Hungarian Institute for the Agricultural Quality Control lend a hand to the labour of NAMB (ZENGÖ, 1998). It is important, that there are noteworthy populations of Mangalica in Switzerland, Germany, Austria and some breeding animals are kept in Yugoslavia and Romania too. The number of these breeding sows is shown in Table 3. The Swallow-Belly type has the largest population, these pigs are kept like hobby animals and for its meat. The animals are on extensive housing conditions, pastured and fed mainly pigswill. The meat quality of Mangalica is much better than any other commercial breeds and properly well for barbecue (FLEGLER, 1999). Furthermore, the content of unsaturated fatty acids of lard is more than $60 \%$ (CSAPÓ et al., 1999).

Table 3

Mangalica stock in Europe (Bestand an Mangalitza in Europa)

\begin{tabular}{|c|c|c|c|c|c|c|c|}
\hline \multirow[t]{2}{*}{ YEAR } & \multirow{2}{*}{$\begin{array}{c}\text { RED } \\
\text { MANGALICA } \\
\text { Germany }\end{array}$} & \multicolumn{3}{|c|}{$\begin{array}{c}\text { SWALLOW-BELLY } \\
\text { MANGALICA }\end{array}$} & \multirow{2}{*}{$\begin{array}{c}\text { BLOND } \\
\text { MANGALICA } \\
\text { Germany }\end{array}$} & \multirow{2}{*}{$\begin{array}{c}\text { MANGALICA } \\
\text { Yugoslavia }\end{array}$} & \multirow{2}{*}{$\begin{array}{c}\text { MANGALICA } \\
\text { Romania }\end{array}$} \\
\hline & & Switzerland & Austria & Germany & & & \\
\hline 1983 & $*$ & $*$ & $*$ & $*$ & $*$ & $*$ & 500 \\
\hline 1992 & $*$ & 80 & $*$ & $*$ & $*$ & $*$ & $*$ \\
\hline 1994 & $*$ & 125 & $*$ & * & $*$ & $*$ & 30 \\
\hline 1996 & $*$ & 105 & $*$ & $*$ & $*$ & $*$ & 34 \\
\hline 1997 & 50 & 105 & $*$ & 45 & 60 & $*$ & $*$ \\
\hline 1998 & 32 & $*$ & $*$ & 63 & 48 & $*$ & * \\
\hline 1999 & 29 & $*$ & 70 & 55 & 43 & 19 & $*$ \\
\hline 2000 & 45 & $*$ & $*$ & 80 & 45 & $*$ & $*$ \\
\hline 2001 & $*$ & 182 & $*$ & $*$ & $*$ & $*$ & $*$ \\
\hline
\end{tabular}

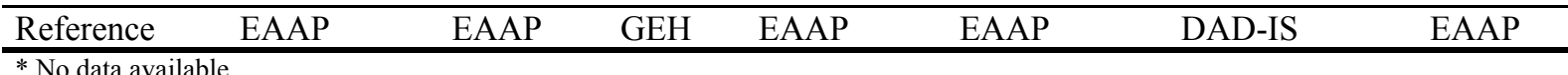

* No data available
EAAP - European Association of Animal Production; GEH - German Safeguard Society of Ancient and Endangered Domestic Animal Breeds; DAD-IS - Domestic Animal Diversity Information System

\section{Reproductive Performance}

Litter size is one of the major components of sow's productivity and hereby a very important economical parameter in pig production. The litter size is determined by the number of ovulation, early embryonic loss and uterine capacity, which are determined by genes and influenced by environmental factors. Furthermore the reproductive efficiency of sows depends from the age of first mating, lactation length, weaned piglets and farrowing interval (VAN DER LENDE et al., 1994). The differences in mean litter size of Mangalica between 1955-1994 are shown in Table 4.

As mentioned above, breeding gilts were kept on pasture and wasteland before mating at the age of $15-18$ month. However, rearing of breeding animals under natural conditions - all day on pasture, in winter in pens and feeding alfalfa-rich fodder - can advance the onset of puberty, and first mating can be performed by the age of 11 month (GÁBOS, 1935). At the beginning of last century for more intensive breeding farrowing was proposed twice a year or in larger stock three times in two years 
(JANISH, 1908). It was recommended to time the farrowing at February and August. As a result sows could farrow altogether $6-7$ times and then were slaughtered at younger age (KOVÁCSY, 1903, 1908). Furthermore the housing conditions and nutrition should be improved with more intensive breeding (JUHOS, 1912). However after the $1^{\text {st }}$ World War the mean litter size decreased to 3.3 after farrowing twice a year but could be increased to $4-4.5$ piglets by farrowing once a year. It was proposed to mark sows according to their fecundity (KOVÁCSY, 1918). Some good results were realised in few Mangalica breeding stocks selecting for prolificacy. The mean litter size increased from 5.5 to 6.44 piglets in a four-years interval (TÉGLÁSSY, 1917), whereas 7 - 8 piglets were attained with conscious selection for litter size and with improved nutrition (KISS, 1926). Since 1927 the breeding sows were registered in herd-books. In 1932 the mean litter-size of 3,133 sows was 6.87 (RÁCZ, 1932). Ten years after the foundation of NAMB in 1937 with more than 7,000 sows the result of the conscious breeding was 1,3 piglets more per litter (6.3 vs. 5.0) and 20 percent of the breeding sows farrowed on average 6.5 - 7.5 piglets (BLANTZ, 1938).

Table 4

References on mean litter size of Mangalica (1955-1994) (Literaturangaben zur Wurfgröße bei Mangalitza)

\begin{tabular}{ccccc}
\hline YEAR & NUMBER OF SOWS & \multicolumn{2}{c}{ LITTER SIZE } & REFERENCE \\
\hline 1955 & 1474 & day 1 p.p. & day 21 p.p. & BALTAY, 1983 \\
1960 & 948 & 6.5 & 5.7 & \\
1965 & 861 & 6.6 & 5.9 & SZABÓ,1999 \\
1967 & 287 & 6.9 & 5.9 & \\
1968 & 83 & 6.9 & 5.9 & BALTAY, 1983 \\
1969 & 122 & 6.7 & 5.9 & SZABÓ,1999 \\
\hline 1970 & 155 & 6.1 & 5.6 & BALTAY, 1983 \\
1971 & 112 & 6.2 & 5.7 & \\
1972 & 44 & 6.1 & 5.2 & \\
1975 & 34 & 5.7 & 4.5 & \\
1976 & 43 & 4.5 & 4.1 & \\
1977 & 5.0 & 4.8 & 4.8 & \\
1978 & 75 & 5.3 & 4.0 & \\
1979 & 117 & 5.6 & 4.4 & \\
1980 & 113 & 5.0 & 4.8 & \\
1990 & 111 & 5.5 & 4.2 & \\
1991 & 348 & 5.3 & 4.3 & \\
1992 & 222 & 4.8 & 4.6 & \\
1993 & 243 & 4.9 & 4.5 & \\
1994 & 201 & 5.1 & & \\
\hline
\end{tabular}

Under optimal breeding conditions the first mating could be performed at 11 month of age with 6.7 piglets/sow (GÁBOS, 1935). Relationship was found between the reproductive performance and the age of the sows, the parity and the number of teats. The number of piglets increased with the parity until the third farrowing and slowly decreased thereafter (RÁCZ, 1932; MENTLER, 1958). According to the analysis of herd book data (CSUKÁS, 1942) the mean litter size was 6.66. The "average" Mangalica sow was the most prolific at the age of $5.5-6$ years, what coincided with the $3^{\text {rd }}$ (one litter yearly) or the $6^{\text {th }}$ (two litter/year) farrowing. In the former Soviet Union good results were achieved with Mangalica by selection for prolificacy. The mean litter size increased from $6-7$ to $8-8.9$ piglets (RED'KIN and KOZLOVSZKIJ, 1952). In an other report three groups of sows with different fecundity were investigated. It was concluded, that with appropriate nutrition and selection the litter 
size can be increased to 8 - 9 piglets and the farrowing rate to more than 1.5 litter/year (SCHALBERT, 1967).

The importance of selection for reproductive efficiency was emphasized with relation to the number of teats (JUHOS, 1912). The number of teats was 10 in $87.6 \%$ of herdbook-sows and $12.4 \%$ of them had more than 10 teats. Sows with more than 10 teats had $25-30 \%$ higher prolificacy (RÁCZ, 1932). Otherwise, no relationship was found between number of teats and fecundity (SCHALBERT, 1967).

It is important, that the larger number of offspring requires more milk for nursing the piglets. How the lactation of the breed can be characterised? The milk yield of sows varied between 119.3 - $190.6 \mathrm{~kg}$ during the 8 - 10-weeks suckling period (RÁCZ, 1932). HORVÁTH (1957) reported on 198 - $327 \mathrm{~kg}$ milk during a 70 days-long period. With quality nutrition milk volume has been increased and was sufficient to rear 8 - 9 piglets. KOVÁCS (1954) estimated 170-235 kg milk with high individual variation, whereas $44.7-49.8 \%$ of the overall milk volume was suckled by piglets during the first 4 weeks of lactation.

Several authors referred that the negative/contra selection was the main reason of the low reproductive performance of Mangalica. The animals were selected for breeding according to its build and maturity (KERTÉSZ-KOVÁCS, 1953). Furthermore the nutrition mainly with maize limited reproduction (TÓTH, 1962). The quality and quantity of nutrition had influence on the prolificacy. The mean litter size was 0.9 piglets larger in sows with quality feeding, and with additional 0.3 piglets in spring farrowing sows (KERTÉSZ-KOVÁCS, 1953). The inheritability of litter size and weight was twice as much than in other swine population in Europe. Some new information about reproductive performance of pure- and crossbred Mangalica are summarised in Table 5.

Table 5

Reproductive performance of pure- and crossbred Mangalica (SZABÓ, 2002) (Reproduktionsleistungen von reinrassigen Mangalitza und Kreuzungssauen)

\begin{tabular}{|c|c|c|c|c|c|c|}
\hline & \multicolumn{3}{|c|}{ Mangalica } & \multirow{2}{*}{$\begin{array}{c}\text { Mangalica } \\
\text { total }\end{array}$} & \multirow{2}{*}{$\begin{array}{c}\text { Duroc x } \\
\text { Mangalica }\end{array}$} & \multirow{2}{*}{$\begin{array}{c}\text { Mangalica x } \\
\text { Cornwall }\end{array}$} \\
\hline & Blond & $\begin{array}{c}\text { Swallow- } \\
\text { Belly }\end{array}$ & Red & & & \\
\hline Number of litter & 71 & 74 & 110 & 255 & 41 & 45 \\
\hline Litter/year & 1.90 & 1.81 & 1.86 & 1.86 & 1.86 & 1.80 \\
\hline Litter size & 6.66 & 6.64 & 6.83 & 6.73 & 7.60 & 7.43 \\
\hline Rearing (\%) & 88.0 & 88.9 & 87.6 & 88.0 & 87.5 & 92.3 \\
\hline Pigs/sow/year & 11.13 & 10.68 & 11.12 & 11.0 & 14.14 & 12.35 \\
\hline
\end{tabular}

There are less information about the ovarian features, on oocyte quality, early embryonic and foetal development, and on losses in this breed. At first BULATOVICI (1932) studied the ovaries and foetal development of slaughtered Mangalica sows. The average number of corpora lutea was 9.88 compared to 12.36 and 12.60 in Berkshire and Yorksire sows. The mean number of foetuses was 5.67, 8.94 and 9.84, respectively. According to BULATOVICI (1932) the main reason of lower prolificacy may be the low number of matured oocytes. In swine there is $30-40 \%$ difference between potential and real reproductive performance, and fecundity is influenced by inheritable and variable environmental factors. Nutrition has an important effect on reproduction, especially the protein and vitamin supply. The early embryonic loss was estimated to be $20 \%$ in Large White and 30\% in Mangalica. Higher protein intake 
decreased the proportion of early embryonic losses with $3.3 \%$ in Mangalica, but had no influence on foetal loss (BECZE, 1962, 1965).

Our research group has been working with Mangalica since 1996 to find a sufficient method for the propagation of this endangered breed and to elucidate the reason(s) of lower prolificacy. Inter-breed embryo transfer was used for the propagation. At first an appropriate superovulatory treatment was selected (RÁTKY and BRÜSSOW, 1998). Thereafter surgical or endoscopical embryo collection and embryo transfer were carried out. It was concluded that an appropriate inter-breed ET program is a suitable tool to propagate the endangered Mangalica breed (RÁTKY et al., 2001). Furthermore the intrafollicular development of oocytes after endoscopic ovum pick up was analysed and compared to Landrace gilts. Results confirmed the lower number of preovulatory follicles in Mangalica in contrast to Landrace gilts (6.8 \pm 1.4 vs. $19.6 \pm$ $6.6 ; \mathrm{p}<0.05)$. Inter-breed differences were obtained concerning the morphology of recovered cumulus-oocyte-complexes. The per cent of oocytes with compact cumulus was higher in Mangalica than in Landrace gilts (31 vs. $16 \%$ ) but less oocytes possess expanded cumulus (62 and $78 \%, \mathrm{p}<0.05)$. The meiotic configuration of oocytes was different between Mangalica and Landrace gilts. The rate of oocytes with mature chromatin configuration (Telophase I /Metaphase II) was higher $(27$ vs. $62 \%, p<0.05)$ in Landrace sows. It is assumed that both diminished follicular development and protracted intrafollicular oocyte maturation may be involved in low fecundity of Mangalica (EGERSZEGI et al., 2001). Ongoing projects deal with aspects of early pregnancy, uterus capacity, and reproductive hormone secretion of this breed, which results will be published later.

\section{Utilisation of the breed}

The Mangalica is one of the fattiest pig in the world, generally $65-70 \%$ of the carcass is lard. The lean meat is only $30-35 \%$ compared to over $50 \%$ in modern breeds. However, its meat quality, taste and consistence are unexcelled. It must be kept in mind that the softness and taste of meat depends on the interstitial fat layers lacking in most commercial breeds. The Mangalica has the necessary amount of fat and the taste satisfy any expectation. During the nineteenth and at the beginning of the twentieth century lard and bacon were the main food of the Hungarian people and the leading export products of the country. In the 1910 -ies till the $1^{\text {st }}$ World War more than 500,000 pork were exported to Europe yearly (ENESEI DORNER and KOVÁCSY, 1926; RÁCZ, 1932). Beginning with the turn of the twentieth century, diet and consumption habits have been changed. There was an increased demand to lean meat and the market preferred butter and vegetable oils against lard. It was a great challenge for the breeders and researcher to work out appropriate programmes to develop a more prolific, faster growing and less fatty Mangalica. In 1927 the NAMB preferred selection methods for improvement of Mangalica (BLANTZ, 1938). In the 1950-ies had begun intensive hybridisation of Mangalica with different commercial breeds by the Research Institute for Animal Breeding of Hungary (HORN et al., 1952a, b, c; CSIRE et al., 1953; KAZÁR, 1953; VINCZE, 1957). The produced pork could meet well the requests of salami manufactures (CSIRE et al., 1960; VINCZE, 1960, 1963). As it was mentioned, Mangalica nearly disappeared due to undesirable fatty meat and lower fecundity compared to modern breeds. After nearly a thirty years break Mangalica was rediscovered at the beginning of 1990-ies, and several programmes and 
research projects have been commenced to preserve and exploit this breed. Nowadays, its traits like adaptivity to extreme and extensive housing conditions, stress and disease resistance, motherliness and excellent meat quality (taste) are requested. For example, Mangalica are well fitted to care sensitive natural areas like dike meadows, bird preserves or chestnut-groves (MICKLICH and MATTHES, 1999; SVWS, 2000). New analysis of carcass demonstrate $<40 \%$ of lean meat and was sufficiently to produce high quality cured ham (SZABÓ, 2001; 2002). The fatty acid composition and the cholesterol content of lard were determined in pure- and crossbred Mangalica, and Hungarian Large White $\mathrm{x}$ Hungarian Landrace. The content of unsaturated fatty acids of lard was over $60 \%$ in Mangalica and nearly $60 \%$ in Mangalica crossbred animals (CSAPÓ et al., 1999; SZABÓ, 2001). Most of these fatty acids were oleic (43.6 $44.8 \%)$ and linoleic acid (10.6 - 11.5\%); the cholesterol concentration did not differ significantly between breeds (CSAPÓ et al., 1999). It was referred that $68.7 \%$ of the intra muscular fat content in $\mathrm{m}$. longissimus dorsi was composed from unsaturated fatty acids, which was at least $6 \%$ more than in German Landrace and German Sattelschwein (ENDER et al., 2002).

A large project was created under the name of "Real Mangalitza" by Olmos and Tóth Ltd. in 1991. The aim of the project is both to preserve the breed and to produce pork for high quality meat products. The fattening up to a weight of $140-160 \mathrm{~kg}$ and slaughter of these animals are carried out in Hungary, whereas most of ham and pork chops are transported to Spain to produce special cured meat products. In Hungary a part of the meat is processed for smoked bacon and sausage. Nowadays the market requires more than 20,000 items of Mangalica products a year, in consequence the preservation of the breed seems to be unravel. Nowadays both the Mangalica breeding stock and all porker are kept under extensive conditions in large pens or on pasture, and are fed mixture of maize, wheat, barley and green fodder.

\section{Conclusion}

Conservation and propagation of domestic animal diversity can be considered as a form of insurance since preserved stocks will possess potential economic, scientific and sociocultural benefits.

The Mangalica pig is a representative example for the success of preserving endangered breeds. Its population is continuously increasing in all colour types although the number of Swallow Belly and Red Mangalica is still critical. The new demand for Mangalica products on the market, the valuable properties of the breed and the reminiscence to the tradition of Hungarian swine breeding will support to preserve the Mangalica as a diverse European pig breed.

BALTAY, M.:

\section{References}

Swine breeds and hybrids in Hungary. (Magyarországi sertésfajták és -hibridek) Mezőgazdasági Kiadó. (1983), 43-53

BECZE, J.:

The reduction of the lower progeny owing to foetal loss in pig breeding. (A magzat elhalás miatti szaporulatcsökkenés kiküszöbölése a sertéstenyésztésben) Állattenyésztés 11 (1962) 1, 93-95

BECZE, J.:

Investigation of the relationships between protein feeding and prolificacy in sows, with regard to partial infertility manifested itself in foetus mortality. (A fehérje takarmányozás és a szaporaság közötti 
összefüggés vizsgálata kocában tekintettel a magzatkori veszteségben megnyilvánuló részleges meddőségre) Állattenyésztés 14 (1965) 3, 251-258

BLANTZ, J.:

Results of 10 years working of the National Association of Mangalica Breeders (A mangalicatenyésztők országos egyesülete 10 éves munkásságának eredményei) Budapest „Pátria” Irodalmi Vállalat és BODO, I.: Nyomdai Részvénytársaság. (1938)

What descend on us, that we have. (Ami ránk maradt, az megvan) Állattenyésztõk Lapja. 15 (1997) 5, 6 BULATOVICI, G.T.:

Beitrag zum Studium der Ursachen der geringen Fruchtbarkeit beim Mangalitza-Schwein. Doktori értekezés. Ref. Züchtungskunde, 7 (1932), 21

CSAPÓ, J.; HÚSVÉTH, F.; CSAPÓNÉ-KISS, ZS.; HORN, P.; HÁZAS, Z.; VARGÁNÉ-VISI, É.; BÕCS, K.: Fatty acid and cholesterol composition of the lard of different genotypes of swine. (Különbözõ fajatájú sertések zsírjának zsírsavösszetétele és koleszterintartalma) Acta Agraria Kaposvariensis 3 (1999) 3, 113

CSIRE, L.; KOVÁCS, J.; MENTLER, L.:

Prolificacy and upbringing rate of sows composite from Mangalica sows and different genotypes of meat type boars. (Mangalica kocáknak különböző hússertés fajtájú kanokkal történt keresztezéséből származó kocák szaporasága és malacainak szopóskori fejlődése) Állattenyésztés 2 (1953) 2, 116-127

CSIRE, L.; MENTLER, L.:

Comparative investigations of the gain in weight, feeding conversation rate and meat-lard ratio during the fattening of the offsprings of Mangalica and crossbred Mangalica sows. (Összehasonlító vizsgálatok a mangalica és a mangalica keresztezésü (F1) kocák ivadékainak hízlalás alatti növekedéséröl, CSUKÁS, Z: takarmányértékesítéséről, valamint a termelt hús- és zsír arányáról) Állattenyésztés 9 (1960) 1, 63-69

Uninheritable factors of the prolificacy of Mangalica. 1. The age and litter size. (A mangalica szaporaságát befolyásoló nem öröklődő tényezők. 1. Az életkor és az alomnépesség) Különlenyomat a CZILCHERT, R.: „Mezőgazdasági Kutatások” 15 (1942) 6, 199-218

Conceptions of animal breeding. (Állattenyésztési eszmék) Pest Nyomtatott Herz Jánosnál. XXIVXXV (1859), 139-148

EGERSZEGI, I.; TORNER, H.; RÁTKY, J.; BRÜSSOW, K.P.:

Follicular development and preovulatory oocyte maturation in Hungarian Mangalica and Landrace gilts. Arch. Tierz., Dummerstorf 44 (2001), 413-419

ENESEI DORNER, B.:

The swine in Hungary. (A sertés Magyarországban) (1908), 42-48

ENESEI DORNER, B.:

Swine breeding. (Sertéstenyésztés) Budapest "Pátria" Irodalmi Vállalat és Nyomdai Részvénytársaság. (1921), 1-15

ENESEI DORNER, B.:

Swine breeding and fattening. (A sertés tenyésztése és hízlalása) Bp. Az Athenaeum Irodalmi és Nyomdai R.T. Kiadása. 81-84 (1925), 134-141

ENESEI DORNER, B.; KOVÁCSY, B.:

Animal breeding in Hungary 3rd Vol. Swinebreeding. (Magyarország állattenyésztése 3. kötet) A sertés tenyésztése. Bp. "Pátria" (1926), 16-56.

ENDER, K.; NÜRNBERG, K.; WEGNER, J.; SEREGI, J.:

FLEGLER, J.:

Fleisch und Fett von Mangalitza-Schweinen im Labor. Fleischwirtschaft 6 (2002), 125-128

GÁBOS, D.:

Das Wollschwein. Gefährdete Nutztierrasse des Jahres 1999. Informationsbroschüre GEH (1999)

HANKÓ, B.:

Principles of Mangalica breeding. (A magyar mangalica belterjes tenyésztésének alapelvei) Bp. "Pátria" Irodalmi és Nyomdai RT. (1935)

Ancient domestic animals of Hungary. (Ösi magyar háziállataink) Debrecen Tiszántúli Mg-i Kamara. (1940)

HOESCH, F.:

Die Schweinezucht. Verlag von M. \& H. Schaper. (1911), 223-228

HORN, A.; KERTÉSZ, F.; MENTLER, L.:

Reciprocal crossing of Mangalica and Berkshire and benefits of their offsprings. (A mangalica $x$ berkshire sertések reciprok keresztezése és utódaik viszonylagos gazdasági haszonértéke) Állattenyésztés 1 (1952a) 1, 44-53

HORN, A.; KERTÉSZ, F.; CSIRE, L.; KAZÁR, G.: 
Some data to the crossbereeding of Mangalica and different genotypes of meat type boars. 2. Growing of the gilts, the feed conversion and quality of the slaughter animals. (Adatok a mangalica kocáknak hússertés kanokkal történő keresztezéséhez. 2. A süldők fejlődése, hízlalása, takarmányhasznosítása és a hízott sertések minősége) Állattenyésztés 1 (1952b) 4, 323-340

HORN, A.; KERTÉSZ, F.; CSIRE, L.:

Some data to the crossbereeding of Mangalica and different genotypes of meat type boars. 1. Growing, feed conversion and resistance of the suckling piglets. (Adatok a mangalica kocáknak hússertés kanokkal történő keresztezéséhez. 1. A szopós malacok fejlődése takarmányhasznosítása és HORVÁTH, L.: ellenállóképessége) Állattenyésztés 1 (1952c) 3, 248-264

Milking of the Mangalica sows and its possible increase. (Mangalica kocák tejelékenysége és JANISH, L.: tejelékenységük fokozásának lehetősége) Állattenyésztés 6 (1957) 2, 117-128

Farrowing of the Manglica twice a year . (A mangalicza sertés kétszeri fiaztatása) Köztelek. 48 (1908) 18,1350

JUHOS, L.:

Warning of farrowing Manglica twice a year. (Intelem a mangolicza kétszeri malaczoztatásánál) Köztelek. 22 (1912) 18, 614-615

KAZÁR, G.:

Reciprocal crossing of the Mangalica and Cornwall breeds and the benefit of their progeny. (A mangalica $\mathrm{x}$ cornwall sertések reciprok keresztezése és utódaik viszonylagos gazdasági haszonértéke)

KAZÁR, J.: Állattenyésztés 2 (1953) 1, 13-22

Registration and livestock judging in swine. (Sertés törzskönyvelése és törzskönyvi küllemi bírálata) Bp. Nyomtatványellátó Vállalat. (1955), 60-67

KERTÉSZ, F.; KOVÁCS, J.:

Some new results to increase Mangalica's prolificacy by nutrition. (Újabb hazai megállapítások a mangalica kocák szaporaságának a takarmányozással elérhető fokozásáról) Agrártudomány 5 (1953) 11, 341-344

KISS, L.:

Increasing of the Mangalica's prolificacy. (A mangalica sertés szaporaságának fokozása) Köztelek. 36 KOVÁCS, J.: (1926), 28-29, 513-514

Some new data on Mangalica's milking performance. (Újabb adatok a mangalica kocák tejtermeléséhez) Állattenyésztés 3 (1954) 3, 233-238

KOVÁCSY, B.; MONOSTORY, K.:

Swine breeding and fattening. (A sertés annak tenyésztése és hízlalása) Kocziányi és Vitéz Kiadó, Kassa (1890)

KOVÁCSY, B.:

Farrowing twice. (Kétszeri malacoztatás) Köztelek 13 (1903) 11, 194

KOVÁCSY, B.:

Farrowing of the Manglica twice a year. (A mangalicza sertés kétszeri malaczoztatása) Köztelek. 18

KOVÁCSY, B.: (1908) 39, 1069

What we have to do for a more prolific Mangalica. (Mit kell tennünk a mangolica sertés szaporábbá tétele érdekében) Köztelek. 28 (1918) 19, 755-756

MATOLCSI, J.:

Origin of the domestic animals. (A háziállatok eredete) Bp. Mezőgazdasági Kiadó. (1975), 170-174

MENTLER, L.:

Some new data to the repeatability of the fecundity and weight of the litter of the Large White and Mangalica sows. (Adatok a fehérhússertés és mangalica kocák szaporaságának, valamint alomsúlyának ismétlöképességéröl) Állattenyésztés 7 (1958) 1, 43-53

MICKLICH, D.; MATTHES, H.D.:

Outdoor keeping of sows of different breeds in a location of a floodplain wood. Arch. Tierz.,

RÁCZ, M.: Dummerstorf 42 (1999), 161-173

Registration and livestock judging of the Mangalica. (A mangalica sertés bírálata és törzskönyvelése) RÁCZ, M.:

Bp. Pátria Irodalmi és Nyomdai RT. (1930)

Mangalica breeding in Hungary. (Magyarország mangalicasertés tenyésztése) Különlenyomat Az Állattenyésztők Lapja (1932), 11-16

RÁTKY, J., BRÜSSOW, K.P.: 
Ovarian activity in gilts including some characteristics of a native breed. Reprod. Dom. Anim. 33 (1998), 219-222

RÁTKY, J.; BRÜSSOW, K.P.; SOLTI, L.; TORNER, H.; SARLÓS, P.:

Ovarian response, embryo recovery and results of embryo transfer in a Hungarian native pig breed Theriogenology 56 (2001), 969-978

RED'KIN, A.P.; KOZLOVSZKIJ, V.G.:

Use of Mangalica in commercial crossing. (Mangalicasertések felhasználása haszonállatelőállító

SCHALBERT, J.: keresztezéshez) Agrártudomány 4 (1952) 10, 338-342

The relationship between the prolificacy of Mangalica sows and the fattening performance and carcass quality of their progeny. (A mangalicakocák szaporaságának valamint ivadékaik hizlalási és vágási SVWS: eredményeinek összefüggése) Diss., Debrecen - Gödöllö, 1967

SZABÓ, P.:

Mangalitza - das Wollschwein. Informationsblatt der Schweizerischen Vereinigung für die Wollschweinzucht (2000)

SZABÓ, P.:

The Mangalica. (A mangalica) Kistermelök Lapja, 12 (1999), 14-15

Achievement in Mangalitza crossbreeding. In: SAVE-DAGENE International Meeting of Mangalica SZABÓ, P.: Breeders Budapest (2001)

Theriogenological results of alternative pig breeds. (Alternatív sertésfajták szaporodásbiológiai eredményei) In: Innováció, a tudomány és a gyakorlat egysége az ezredforduló agráriumában, Debrecen (2002), 97-102

TÉGLÁSSY, A.:

Some words about the breeding of the Mangalica. (Néhány szó a mangalica tenyészetérõl) Köztelek 27 (1917) 19, 764-765

TÓTH, S.:

Heridity of prolificacy, litter-weight on the 30 and 60 days in two Mangalica stocks. (A szarvasi és a mezőhegyesi mangalica állomány szaporaságának, 30 és 60 napos alomsúlyának örökölhetősége) Állattenyésztés 11 (1962) 1, 43-46

VAN DER LENDE, T.; SOEDE N.M.; KEMP, B.:

Embryo mortality and prolificacy in the pig In: COLE, D.J.A.; WISEMAN, J.; VARLEY, M.A. (Eds.), Principles of pig science. Nottingham University Press (1994), 297-317

VINCZE, L.:

Comparative investigation of the crossbreeding of the Mangalica sows and Cornwall boars. (Összehasonlító kísérletek mangalica kocák hasznosításának megjavítására cornwall kanokkal történő keresztezés útján) Állattenyésztés 6 (1957) 3, 199-213

VINCZE, L.:

Investigations of heavy weight fattened lard pigs for the supply of sausage manufacture with raw material. (Vizsgálatok nehézsúlyra hizlalt zsírjellegü sertésekkel a téliszalámi ipar nyersanyagigényének leggazdaságosabb kielégítésére) Állattenyésztés 9 (1960) 4, 315-324

VINCZE, L.:

Some new data for the supply of the sausage production with raw data. (Újabb adatok a téliszalámigyártás nyersanyagigényének biztosításához) Állattenyésztés 12 (1963) 2, 157-168

ZENGÖ, Á.:

The Mangalica. (A mangalica) Állattenyésztők Lapja 5 (1997), 9

ZENGÖ, Á.:

Present and future of Mangalica. (A mangalica jelene és jövője) A Sertés. 3 (1998) 1, 4-9

Received: 2003-02-26

Accepted: 2003-05-06

Author's addresses

Dipl. Agrar-Ing. ISTVAN EGERSZEGI

Prof. Dr. med. vet. habil JOZSEF RÁTKY

Prof. Dr. vet. med. habil LÁSZLÓ SOLTI

Research Institute for Animal Breeding and Nutrition

Faculty of Veterinary Science

H-2053 Herceghalom / Hungary

Szent Istvan University

H-1400 Budapest / Hungary

Prof. Dr. rer. nat. habil KLAUS-PETER BRÜSSOW*

Research Institute for the Biology of Farm Animals

Wilhelm-Stahl-Allee 2, D-18196 Dummerstorf, Germany

*Corresponding author

E-Mail: bruessow@fbn-dummerstorf.de 